\title{
O QUE É CRÍTICA. OU: QUAL É A CRÍTICA DA GEOGRAFIA CRÍTICA?
}

\author{
José William Vesentini*
}

\section{RESUMO}

Este texto procura problematizar o que é crítica. Para isso realiza um breve histórico do vocábulo desde a Grécia antiga, onde surgiu, até Kant, pensador que redefiniu essa atitude. De fato, a partir de Kant - inclusive em autores como Hegel, Marx, Adorno, Habermas e outros - crítica passou a ser vista como superação com subsunção e como engajamento num projeto de autonomia. Além disso, este ensaio procura verificar como o termo crítica tem sido entendido na geografia crítica, mostrando que esta é uma questão e um importante debate em andamento nos dias de hoje.

PALAVRAS CHAVE: crítica, autonomia, geografia crítica, pós-modernidade.

\section{ABSTRACT}

This text has tried to understand critical as an intellectual issue. Thereby, a brief history of the word is produced: since the Ancient Greece, where the word was created, until Kant, thinker who redefined this expression and attitude. Indeed, from Kant - include authors like Hegel, Marx, Adorno, Habermas and others - critical means an overcome with subsume and at the same time a commitment in an autonomy project. Moreover, this essay has tried to verify how the word critical has been understood in the critical geography, showing that this is an important question and argument that has gone on nowadays.

KEY WORDS: critics, autonomy, critical geography, postmodernism.

Geografia ou geografias críticas. A bibliografia da/sobre essa vertente geográfica já é bastante significativa. Entretanto, uma dúvida se impõe: o que é crítica? Em que sentido esse verbete vem sendo empregado na(s) geografia(s) crítica(s)? Qual é, afinal, o significado do adjetivo crítico, frequentemente utilizado, algumas vezes com diferentes sentidos, em várias áreas do conhecimento? (Basta lembrarmos das ideias de reflexão crítica, atitude crítica, teoria crítica, pensamento crítico, ensino crítico, pedagogia crítica, racionalismo crítico e inúmeras outras).

Esta preocupação, longe de ser diletante ou superficial, é algo que se impõe fortemente com as mudanças na realidade social, em especial com a crise terminal do antigo mundo socialista e com a relativização das noções políticas de esquerda e direita, que para muitos não têm mais sentido na realidade atual. Como iremos esquadrinhar logo adiante, a noção de crítica (especialmente a crítica social) a partir da Revolução Francesa e principalmente no transcorrer do século XIX viu-se associada à ideia política de uma esquerda, isto é, àqueles que propugnavam uma mudança radical na sociedade com vistas a uma maior igualdade e liberdade. Por isso tornou-se muito comum a idenfificação das noções de crítica e de radical, que também iremos problematizar. 
Para início de conversa, a verdade é que ninguém mais sabe ao certo o que é esquerda e direita hoje. Isso por várias razões. Pelo fracasso de todas as experiências autodenominadas socialistas, fundamentadas bem ou mal no marxismo e tendo se apresentado como "críticas" ao capitalismo e alternativas "radicais" a ele. Pela crescente complexização da sociedade moderna, em especial com o declínio das lutas trabalhistas que tanto marcaram o século XIX e a primeira metade do $X X$, lutas essas sempre identificadas com a esquerda e com todas as vertentes libertárias ou socialistas. Pelo advento de novos sujeitos e frentes de lutas no plural - feministas, ecológicas, étnicas, de orientação sexual, de moradia, imigrantes de regiões pobres em áreas mais desenvolvidas, etc. -, que por vezes são até antagônicos. Pela expansão e o enorme poderio da mídia, que juntamente com as pesquisas de opinião faz com que praticamente todos os partidos políticos reformulem os seus discursos em função do que o público quer neste ou naquele momento independentemente de sua posição ideológica (se é que isso ainda existe). Por tudo isso, reiteramos, as noções de esquerda e direita tornaram-se problemáticas para definir todo um espectro de posições políticas no mundo atual. Existe ainda uma perda de referências. A grande bandeira de luta da velha e heroica esquerda, aquela do século XIX e da primeira metade do século $X X$, a de uma sociedade utópica $^{1}$ que garantisse concomitante o máximo de liberdade e de igualdade, foi completamente destroçada por inúmeros acontecimentos e estudos científicos: pela triste realidade de todos os socialismos reais, em primeiro lugar, e também por pesquisas e reflexões lógico-matemáticas, tais como, por exemplo, aquelas do prêmio Nobel de economia Amartya SEN (2001), nas quais se demonstra cabalmente que é impossível existir um máximo de igualdade sem sacrificar a liberdade e vice-versa.

Nesses termos, alguns autores que se consideram progressistas e apregoam um mundo melhor, com maior justiça - entendida como garantias para as liberdades democráticas, que não são algo eterno e acabado e sim partes de um processo de constante criação e reinvenção de direitos - e igualdade (embora nunca total), falam em ir "além da esquerda e da direita" (LEFORT, 1983; GIDDENS, 1995), enquanto que alguns poucos outros despendem os maiores esforços no sentido de conservar, embora redefinindo, essas categorias políticas (BOBBIO, 1995; FAUSTO, 2007).

A manutenção desses rótulos - algo que no Brasil e na América Latina em geral é um esforço quase exclusivo da autodenominada "esquerda", sendo que nos Estados Unidos, ao inverso, é mais identificado com os conservadores - não deixa de pagar um elevado preço teórico. De fato, trata-se mais de um apego a uma identidade vista como "positiva" (esquerda na América Latina e direita nos Estados Unidos), que no fundo faz parte da autodefinição de certas pessoas e grupos, uma tentativa de se manter fiel a um certo passado (ou a determinadas tradições), e no extremo - no caso de alguns partidos - é algo que visa angariar simpatias e votos.

Sem dúvida que existem teóricos sérios e bem intencionados que procuram manter esses rótulos políticos. Não estamos nos referindo a autores panfletários com visíveis insuficiencias teóricas, que não conseguem ir além do marxismo-leninismo, do tipo Ignácio Rangel, Emir Sader, Robert Kurz e outros, que escrevem como se ainda vivéssemos no século XIX, que se recusam a analisar seriamente - e aprender com - a experiência dos totalitarismos (nazismo, fascismo e comunismo), que menosprezam as conquistas democráticas. Pensamos em teóricos do calibre de Norberto BOBBIO (1995) e Ruy FAUSTO (2007), entre alguns poucos outros. Bobbio, por exemplo, acredita que a esquerda hoje define-se fundamentalmente pela busca de uma maior igualdade social, enquanto que a defesa da liberdade seria mais um atributo da direita. E Fausto pensa que uma esquerda nos dias atuais deve ser defensora intransigente da democracia - por sinal, Bobbio também advoga essa posição, embora identificando democracia com o liberalismo, algo que Fausto repudia - e ir além do marxismo (posição também defendida pelo liberal Bobbio), deixando de lado a ideia de 
uma "ditadura do proletariado" (ou de qualquer outro tipo de ditadura) e mesmo a de uma economia planificada sem a propriedade privada nos moldes genericamente apontados por Marx, recuperando o ideal anarquista e socialista utópico de autogestão, de cooperativas de pequenos produtores ou trabalhadores, etc.

Essas proposições, contudo, embora sejam as mais palatáveis (sem dúvida que as mais democráticas) entre os que se autointitulam de esquerda, nos parecem em certa medida frágeis. Primeiro, no caso de Bobbio, significaria deixar de lado os reclames por liberdades (contra as prisões arbitrárias e a tortura, contra a violação dos direitos humanos, pela ampliação dos direitos das mulheres, dos homossexuais, das etnias minoritárias, dos idosos, etc.) para a direita, algo evidentemente absurdo e oposto a toda tradição progressista da esquerda. É certo que Bobbio assinalou que a liberdade que a direita mais defende é a do mercado, mas mesmo assim insistiu que a bandeira de luta da esquerda é basicamente a igualdade e não as liberdades. E mesmo a liberdade do mercado - algo que nos dias atuais inclui a proteção dos consumidores, o combate aos cartéis e monopólios, inclusive àqueles estatais, etc. - é fundamental para qualquer democracia moderna na medida em que ainda não foi encontrado um substituto aceitável. Durante algum tempo pensou-se que a estatização e a planificação da economia fossem melhor que o mercado, mas isso já foi completamente descartado ao ponto de alguns autores da new left, inclusive economistas que participaram de planos quinquenais na Hungria e na China na época em que vigorava a economia planificada, terem afirmado que se houver um novo socialismo no século XXI sem dúvida que ele terá por base a economia de mercado (cf. NOVE, 1989). Depois, existe o fato óbvio de que somente a vigência da democracia, logo das liberdades e da participação, é que pode garantir um mínimo de igualdade - mas nunca total, pois isso é um sonho utópico no sentido literal da palavra [isto é, "que não existe em lugar algum"], tal como a ilha imaginada por Thomas Morus. Na prática, a própria vigência das liberdades conduz a uma certa desigualdade na medida em que as pessoas e os grupos são desiguais nas suas potencialidades, nas suas necessidades, no seu valor de barganha para a sociedade, na criatividade ou nas formas de luta, etc. E tentar impor uma igualdade total através da única forma possível, qual seja, pela força através de um regime não democrático - um partido único no poder (ou um líder carismático) que diz representar os trabalhadores ou o povo -, como foi demonstrado ad nauseam, é algo que sempre resulta em privilégios abusivos para alguns, que mandam e desmandam de forma arbitrária, que usam em seu proveito pessoal os bens tidos como públicos. Quanto à posição de Fausto, acredito que de fato seja interessante investir esforços na busca de alternativas libertárias do tipo economia com base em cooperativas, autogestão em empresas e outras instituições, etc. O problema é que muitas vezes essas experiências cooperativas ou autogestionárias resultam na ditadura de uma pessoa ou um grupo. Ou então na promoção de interesses corporativos - ou de grupelhos específicos - que são opostos aos interesses maiores da sociedade. [Não podemos continuar a ser ingênuos hoje, depois de tantas experiências de manipulação de assembleias basta lembrar, sem a menor pretensão em denegar, de inúmeras instrumentalizações da "vontade popular" em alguns orçamentos participativos - a respeito do assembleismo. Via de regra existem partidos ou grupelhos organizados que conseguem impor os seus pontos de vista apriorísticos nas resoluções, seja pelo cansaço da maioria seja pela manipulação dos votos, etc.]. E ao contrário de Bobbio, Fausto não enfrenta o dilema da igualdade versus a liberdade; ele continua - tal como no século XIX - a escrever como se essa antinomia não existisse. Parodiando o título do seu livro, podemos dizer que de fato é difícil ser [inequivocamente] de esquerda - e também de direita - no século XXI.

Essa polêmica evidentemente já chegou na geografia crítica. Desde a última década do século $X X$, logo depois do debacle do socialismo real no Leste europeu e na ex-União Soviética, surgiram várias listas de discussão - ou fóruns, como se denominam - na Internet a respeito do que seria uma geografia crítica hoje ${ }^{2}$. Dando uma 
rápida espiada em algumas dessas mensagens pois é praticamente impossível ler todas (são milhares), algo que provavelmente nem mesmo o mediador de cada um desses grupos faz -, logo se percebe que não existe sequer um mínimo consenso entre os participantes a respeito do que é ou deveria ser uma geografia crítica: para alguns é sinônimo (ou no mínimo complementar) do adjetivo radical, e/ou do adjetivo socialista (embora nunca fique claro que tipo de socialismo), para outros simplesmente de denúncia de grupos neonazistas, de alguma forma de desigualdades ou injustiças, ou de agressões à natureza em qualquer parte do mundo, e assim por diante.

Também em livros e artigos acadêmicos esse debate se encontra em andamento. Dois geógrafos britânicos, apesar de admitirem haver "inúmeras desavenças sobre o que seria esquerda", concluiram o seu artigo de forma extremamente otimista, afirmando que ela hoje "representa o futuro" (THRIFT e AMIN, 2005). Esse texto suscitou um enorme debate. Tanto que já é considerado o ensaio mais citado entre todos os que já foram publicados nessa revista Antipode -, que em 1969 inaugurou a "geografia radical" anglo-saxônica. Nesse mesmo número da revista existe um diálogo com esse texto, por parte de um autor marxista que censura a ênfase no pluralismo em Thrift e Amin e os chama - de forma depreciativa, pois acredita por um motivo obscuro qualquer [não explicitado] que há semelhanças entre o pluralismo científico e a "conversão ao neoliberalismo" da esquerda trabalhista britânica (Tony Blair e outros) - de neocríticos (SMITH, 2005). Logo no ano seguinte veio uma intervenção de uma geógrafa norteamericana, que estranhou tanto otimismo - ou tanta ingenuidade - por parte daqueles dois autores num momento em que inegavelmente a esquerda se encontra em crise (WILLS, 2006). Um outro autor norte-americano, nesse mesmo ano, assinalou - para horror de autores como Smith - que a partir do final dos anos 1980 nos Estados Unidos, por influência do pensamento pós-moderno em ascensão, que gradativamente passou a substituir o neomarxismo como referência teórica nos círculos engajados da geografia acadêmica, pouco a pouco a bandeira de uma "geografia radical" foi sendo substituída pela de "geografia crítica" (BLOMLEY, 2006). Considero pertinente este último ponto de vista, pois na verdade a ideia de uma geografia crítica nasceu primeiramente na França, em 1976, com Yves Lacoste e outros participantes da revista Hérodote, que desde o início se mostraram reticentes em relação ao marxismo e incorporaram ideias de pensadores anarquistas (Réclus) e principalmente pós-modernos (Foucault) ${ }^{3}$. Esse geógrafo francês chegou a afirmar que o marxismo negligenciou o espaço em prol de uma supervalorização do tempo (LACOSTE, 1988: 139-51).

Mas, prosseguindo com o seu pensamento, o mencionado geógrafo norteamericano questiona sobre o que seria de fato uma atitude crítica e coloca a seguinte dúvida: será que todos nós, que dizemos praticar uma geografia crítica, somos realmente críticos? (BLOMLEY, 2006: 87). Ele ainda se pergunta, com base num questionamento de um colega seu da universidade [cujo nome não mencionou], se o adjetivo crítico na verdade não se tornou redundante; e afirma que a tradição crítica nas ciências sociais teria começado com Marx, que num trecho célebre decretou que: "Entretanto os filosófos somente têm interpretado, de várias maneiras, o mundo. A questão principal é transformá-lo" (MARX apud BLOMLEY, 2006). A meu ver, o autor acertou em cheio ao questionar o significado de crítica [ou mesmo de radical, num outro plano] nos dias de hoje. Mas errou completamente ao identificar o conceito de crítica com esse chamado ao engajamento que Marx proclamou em 1845 nas suas Teses contra Feuerbach. Como iremos mostrar a seguir, esse é um tremendo desacerto, típico da geografia anglo-saxônica em geral que, via de regra, não conseguiu discernir os significados (diferentes) de crítica e de radical e tampouco esquadrinhar o longo percurso, que começou muito antes de Marx, da crítica na vida social e política.

Ipso facto, este nosso ensaio constitui uma modesta tentativa de contribuição através de uma releitura dos significados de crítica, em primeiro lugar, e também dos adjetivos radical e esquerda. 
Uma releitura que vai até as origens e procura mostrar as mudanças que a noção de crítica sofreu em alguns momentos históricos cruciais. E principalmente tentaremos polemizar o que significa uma atitude crítica hoje e se essa adjetivação ainda é necessária na geografia do século XXI.

Vamos iniciar pela semântica. No senso comum a palavra crítica normalmente é vista sob um viés negativo, enquanto uma censura ou condenação, como um julgamento sempre desfavorável. Criticar, no entendimento comum amiúde encontrável na mídia, em filmes, em discursos políticos e mesmo em assembleias populares ou trabalhistas, significa basicamente "falar mal" de alguma pessoa, ideia ou teoria, de algum projeto ou de alguma proposição ${ }^{4}$. Entretanto, essa não é a acepção filosófica e cientifica do conceito. $\mathrm{Na}$ filosofia, na epistemologia e nas ciências humanas em geral o significado de crítica é o de um procedimento que implica em discernimento, critério, apreciação minuciosa e julgamento que não precisa ser, necessariamente, negativo. Mais ainda: é um procedimento tido como necessário e até mesmo imprescindível para o aprimoramento e o avanço do conhecimento 5 .

Etimologicamente, a palavra crítica vem do grego kritikòs, que significa o ato de examinar ou julgar alguma coisa. Essa palavra é um derivativo do vocábulo grego krinò, que pode ser entendido como a capacidade de distinguir, de estabelecer uma distinção (cf. SIERRA, 1999; e CARROLI, 2006). Com os gregos da antiguidade, portanto, os criadores do vocábulo, a crítica implicava numa reflexão, num ato reflexivo no qual se avaliava ou examinava alguma coisa: uma ideia, uma teoria, um comportamento, uma peça de teatro, uma obra literária, etc. Uma avaliação tanto dos aspectos positivos quanto dos negativos, um julgamento, digamos assim, da "qualidade" dessa coisa, de sua validade ou veracidade (total ou parcial) e de seus erros ou equívocos (idem).

Michel Foucault procurou datar o momento em que a crítica passa a ter um significado político. Numa conferência pronunciada em 1978 na
Sociedade Francesa de Filosofia, ele afirmou que no Ocidente, com o advento da modernidade, especialmente entre os séculos XV e XVI, a palavra crítica começa a denotar um tipo de posição política, uma oposição ao ato de governar, que, convém recordar, naquele momento se identificava com a nascente monarquia absolutista. Na interpretação desse autor:

"E eu proporia então, como uma primeira definição da crítica, esta caracterização geral: a arte de não ser de tal forma governado. Não querer ser governado assim, não é não mais querer aceitar essas leis porque elas são injustas, porque, sob sua antiguidade ou sob o seu brilho mais ou menos ameaçador que Ihes dá a soberania de hoje, elas escondem uma ilegitimidade essencial. A crítica é então, desse ponto de vista, em face do governo e à obediência que ele exige, opor direitos universais e imprescritíveis, aos quais todo governo, qual seja ele, que se trate do monarca, do magistrado, do educador, do pai de família, deverá se submeter. À questão 'como não ser governado?, responde-se dizendo: 'quais são os limites do direito de governar'?" (FOUCAULT, 1990 : 35-63).

Mas foi com Kant, no século XVIII, que a crítica assumiu o seu significado moderno, praticamente o mesmo posteriormente retomado por Hegel, por Marx e pelos tantos outros filósofos ou cientistas sociais que se utilizaram desse conceito para definir alguma teoria ou corrente de pensamento: Adorno e Horkheimer com a sua teoria crítica, Karl Popper com o seu racionalismo crítico, Paulo Freire e Giroux, dentre outros, com a proposta de uma pedagogia crítica, etc. Tanto que a filosofia kantiana também é conhecida pelo nome de criticismo (LEGRAND, 1986:103-4). Sua monumental obra, Crítica da Razão Pura, é uma tentativa de examinar minuciosamente as propriedades da razão pura, aquela desligada da experiência, estabelecendo os seus limites. Não se trata, porém, de uma radical negação da razão e sim uma autocrítica desta, uma espécie de continuação do projeto iluminista de, utilizando a razão com base na ciência moderna, combater todas as formas de escuridão (ignorância por 
crenças e superstições, dogmatismo religioso, autoritarismo no conhecimento e na vida política). Nas suas palavras:

\begin{abstract}
"O objetivo desta Crítica da razão pura especulativa reside na tentativa de mudar o procedimento tradicional da Metafísica e promover assim uma completa revolução nela segundo o exemplo dos geômetras e investigadores da natureza. (...) Com base num lance superficial de olhos sobre esta obra, poder-se-á pensar que a sua utilidade seja somente negativa, ou seja, de não ousarmos jamais elevar-nos com a razão especulativa acima dos limites da experiência(...) Ela se tornará, porém, imediatamente positiva quando nos dermos conta de que os princípios, com cujo apoio a razão especulativa ultrapassa os seus limites, na verdade têm como resultado inevitável, se o observarmos mais de perto, não uma ampliação mas uma restrição do uso da nossa razão(...) Contestar a utilidade positiva deste serviço prestado pela Crítica equivaleria a dizer que a polícia não possui nenhuma utilidade positiva por ser a sua principal ocupação fechar a porta à violência."
\end{abstract} (KANT, 1974: 14-5).

A crítica, nesses termos, não é somente negativa - o "falar mal" de algo ou mesmo somente apontar lacunas, problemas, insuficiências, contradições -, mas também positiva na medida em que auxilia no avanço ou no aprimoramento do objeto criticado, promove enfim uma revolução no sentido de propor novas alternativas ou perspectivas. Mas o criticismo kantiano ainda vai além. Prosseguindo com a interpretação de Foucault, temos que a crítica kantiana vincula-se à de esclarecimento, isto é, da conquista da maioridade pelo ser humano:

"A definição que Kant dava de crítica não é distante de como ela entendia a Aufklärung [esclarecimento, ilustração]. É característico, com efeito, que, em seu texto de 1784 sobre o que é a Aufklärung, ele a definiu em relação a um certo estado de menoridade no qual estaria mantida, e mantida autoritariamente, a humanidade. Em segundo lugar, ele caracterizou essa menoridade por uma certa incapacidade na qual a humanidade estaria retida, incapacidade de se servir de seu próprio entendimento sem alguma coisa que fosse justamente a direção de um outro (...) Em terceiro lugar, creio que é característico que Kant tenha definido essa incapacidade por uma certa correlação entre uma autoridade que se exerce e que mantém a humanidade nesse estado de menoridade, correlação entre este excesso de autoridade e, de outra parte, algo que ele considera, que ele chama uma falta de decisão e de coragem. (...) Enfim, é característico que, nesse texto Kant dá como exemplos de retenção da menoridade da humanidade, e por conseqüência, como exemplos, pontos sobre os quais a Aufklärung deve erguer esse estado de menoridade $e$ maioridade em, certo tipo, os homens, precisamente a religião, o direito e o conhecimento. O que Kant descrevia como a Aufklärung, é o que eu tentei até agora descrever como a crítica, como essa atitude crítica que se vê aparecer como atitude específica no Ocidente a partir, creio, do que foi historicamente o grande processo de governamentalização da sociedade. Com relação a essa Aufklärung (cujo emblema, vocês bem o sabem e Kant lembra, é 'sapere aude' [atreva a conhecer, a pensar por conta própria], praticamente um contraponto a uma outra voz, aquela de Frederico II, que dizia 'que eles raciocinem tanto quanto querem contanto que obedeçam'). Como Kant vai definir a crítica? Eu diria que a crítica será aos olhos de Kant o que ele dirá ao saber: você sabe bem até onde pode saber? Raciocina tanto quanto queira, mas você sabe bem até onde pode raciocinar sem perigo? A crítica dirá, em suma, que está menos no que nós empreendemos, com mais ou menos coragem, do que na idéia que nós fazemos do nosso conhecimento e dos seus limites, que aí vai a nossa liberdade, e que, por conseqüência, ao invés de deixar dizer por um outro "obedeça", é nesse momento, quando se terá feito do seu próprio conhecimento uma idéia justa, que se poderá descobrir o princípio da autonomia e que não se terá mais que escutar o obedeça; ou antes 
que o obedeça estará fundado sobre a autonomia mesma." (FOUCAULT, 1990: 40).

Nesses termos, a crítica para Kant implica num projeto de autonomia, de libertação da razão das amarras do autoritarismo, do tradicionalismo e das crendices. É uma contribuição para a revolução democrática no sentido de maior autonomia da humanidade e dos indivíduos ou cidadãos, isto é, de ousar pensar o impensável, de raciocinarmos por conta própria independentemente dos dogmas e das proibições. Ou seja, um convite a "mudar o mundo" no sentido de construir uma sociedade com maior justiça e igualdade, com maior progresso científico, com esclarecimento enfim. Não podemos negligenciar que em grande parte a obra de Kant representa uma certa continuação do iluminismo e ao mesmo tempo reflete uma admiração pela Revolução Francesa. Hegel retomou essa ideia de crítica, mesmo procurando à sua maneira superar o criticismo kantiano. Sabemos que ele valorizou a História - com $\mathrm{H}$ maiúsculo, vista como a realização paulatina da razão através de etapas ou avatares, num processo teleológico com um final pré-definido. A dialética para ele, longe de ser apenas um procedimento de oposição (tese e antítese) que gera uma síntese, como em Kant, assume uma dimensão ontológica que aparece sob a forma dos processos históricos. A dialética hegeliana não pretende ser apenas uma forma de lógica, mas também uma ontologia; ela se apresenta como o movimento da História.

Marx prosseguiu com essa ideia hegeliana da dialética como a realização da História, sendo esta uma dinâmica complexa que atravessaria várias fases e afinal desembocaria na completa libertação do ser humano. Afirmando ter colocado Hegel em posição invertida, com os pés no chão, ele substituiu a razão ou o espírito pelas condições materiais e a luta de classes, que também num processo teleológico, por etapas, conduziriam ao socialismo e, após um período de transição, ao comunismo, a História enfim realizada ou acabada. Sua principal obra, O Capital, tem como subtítulo Crítica da Economia Política, numa inegável inspiração kantiana no qual a crítica é uma superação com subsunção e, mais ainda, é um procedimento revolucionário que aponta para uma libertação do ser humano, para uma completa autonomia no futuro. Procurando estabelecer os limites da economia política clássica (de Adam Smith, David Ricardo e outros) - que seria antes de tudo uma economia burguesa ou justificadora do sistema capitalista -, Marx acreditou ter encontrado a sua superação com a análise das contradições do capitalismo, o qual inexoravelmente cederia lugar a um novo modo de produção sem a propriedade privada dos meios de produção. Ao contrário do que pensam alguns, a crítica de Marx ao capitalismo e à economia política não significou uma "crítica negativa" no sentido de apenas apontar erros, problemas, mistificações ou contradições. Como mostrou com propriedade BERMAN (1987: 85-125), é na obra de Marx - muito mais do que na de Ricardo, de Smith, de Keynes ou de qualquer outro autor tido como ideólogo da economia de mercado - que podemos encontrar os mais rasgados elogios ao capitalismo, em especial ao imenso "progresso" que ele promoveu, à sua "missão civilizadora", à criação de um mercado mundial integrado. O sentido que Marx dava ao termo crítica, convém repetir, era o de um procedimento kantiano de entender profundamente algo, inclusive nos seus aspectos positivos, assinalando a sua importância histórica e ao mesmo tempo apontando os seus limites ou as suas insuficiências (ou as suas "contradições", nos termos da dialética hegeliana).

Sabemos que a partir do final do século XIX - e até o final do século XX - a ideia de crítica esteve identificada basicamente com o marxismo, como se fosse um atributo somente da "esquerda" (vista como os adeptos do socialismo) e tendo o capitalismo como objeto privilegiado, o alvo por excelência das críticas. No entanto, ao contrário do procedimento crítico adotado por Marx, o marxismo posterior, com raras exceções, somente viu aspectos "negativos" e inaceitáveis no capitalismo (e mesmo na democracia!), como se este fosse um sistema que de forma inelutável amplia as desigualdades e entrava o "progresso", isto é, o desenvolvimento das forças produtivas. É evidente que, hoje, essa leitura precisa ser 
reexaminada e superada. Precisa ser criticada enfim. Não é mais possível levar a sério a concepção de dialética como portadora do segredo da história, ou como o "método científico" por excelência; e muito menos a existência de um sujeito qualquer (o proletariado, os trabalhadores, o espírito, as massas, a multidão, os movimentos sociais, as ONG's ou qualquer outro agente) que seria o redentor da humanidade. E não apenas o capitalismo, mas também o socialismo real, assim como qualquer outro projeto de sociedade que repudie o mercado e a democracia (por exemplo, aqueles alicerçados em valores religiosos; ou o populismo autoritário "de esquerda" da América Latina), deve igualmente ser objeto de profundas críticas.

Malgrado os equívocos e as insuficiências de Marx e de Hegel - em especial a tentativa de teleologizar a história e a pretensão de identificar um agente portador do futuro e do segredo da história (a razão ou o proletariado) -, não podemos perder de vista o que há de comum entre eles e Kant. Ou, em outras palavras, o entendimento da crítica não como falar mal ou desancar um pensamento, mas sim como compreensão minuciosa dos seus fundamentos e limites, como superação na qual se incorpora o que foi superado como parte de uma síntese ou teoria superior. E ao mesmo tempo crítica como um projeto de autonomia da humanidade, de crescimento do ser humano no sentido de libertação das amarras do tradicionalismo, das crendices, da exploração social e do autoritarismo.

Acreditamos que esta deva ser a concepção reproduzida pela geografia crítica ou pelo menos por grande parte dela, que afinal é plural. Crítica como superação com subsunção e ao mesmo tempo como um engajamento em algum projeto de libertação que amplie o espaço da democracia, que combata todas as formas de dogmatismo e de autoritarismo. Todavia, existe hoje um grande dilema: a ideia de projeto de libertação tornou-se extremamente problemática, embora de maneira alguma dispensável. Mas a profunda compreensão desse fato requer algumas explicações.
Em primeiro lugar, ao contrário do que pensam alguns, não se trata de denegar completamente a geografia clássica ou tradicional, substituindo-a pelo materialismo histórico com os seus conceitos fundamentais (modo de produção, formação econômico-social, classes sociais alicerçadas na produção, a teoria marxista do valor, o socialismo como etapa que substituirá o capitalismo, etc.). Com tal procedimento, mesmo quando existe a tentativa de enriquecer ou completar o marxismo com a incorporação do espaço geográfico - a formação econômico-social transforma-se em formação socioespacial, a luta de classes passa a abarcar os conflitos ambientais e territoriais, o materialismo histórico passa a ser chamado de materialismo histórico-geográfico (HARVEY, 2001: passim), etc. -, não existe uma verdadeira crítica da tradição geográfica. Não há uma superação com subsunção e tampouco um projeto de libertação realista e coerente com a nossa época. O que existe nesse procedimento é apenas a substituição da tradição geográfica por uma teoria do século XIX (mesmo que esta seja lida a partir de algum autor posterior: Lukács, Althusser ou mesmo Léfebvre...) que imaginou ter superado o capitalismo pela análise de suas contradições e limites, que pretensamente conduziriam ao socialismo. Sem dúvida que naquele momento de ascensão dos movimentos operários essa construção teórica era crítica. Mas nos dias de hoje ela se encontra envelhecida, até mesmo caduca, além de completamente deslocada dos verdadeiros projetos de libertação, que não se identificam mais com esse agente idealizado por Marx, o proletariado, o qual, sejamos francos, sequer existe no mundo empírico ${ }^{6}$. Insistir nessa via sem levar em conta a experiência dos totalitarismos do século XX que em boa parte nela se alicerçaram - e as mudanças na vida social e econômica, com o advento de novos sujeitos e campos de luta, nada mais é que, consciente ou inconscientemente, partilhar um projeto de ascensão ao poder por uma camada de burocratas que fala em nome dos trabalhadores, dos excluídos ou da História?.

Destarte, a história do século XX - e em especial a crise do mundo socialista, a emersão de novos sujeitos e formas de luta social, a par 
das profundas mudanças ocorridas no capitalismo, que não pode mais ser entendido pelas análises marxistas clássicas - , evidencia que a crítica da economia política também deve ser criticada, que ela também possui os seus limites e insuficiências, cada vez mais evidentes. Assumir o materialismo histórico como "a" teoria na qual a geografia deve ser diluída é um procedimento acrítico, que não realiza, sequer minimamente, uma análise crítica da geografia, tal como aquela de Kant frente à razão pura, ou mesmo a de Marx frente ao capitalismo. Apenas se incorpora, de forma mecânica e sem grande criatividade, determinados conceitos ou preocupações espaciais a um corpo teórico já constituido, este sim nascido de uma tradição crítica, embora datada e integrada a outros tempos, outras circunstâncias. Pouco se avança no conhecimento da realidade; em geral tão somente velhos chavões ou estereótipos são regurgitados.

Devemos então indagar sobre o que seria um procedimento crítico nos dias de hoje. Nesta época de pós-modernidade com múltiplos sujeitos e verdades, com visões de mundo alternativas e igualmente aceitáveis, cada uma dentro de seu ponto de vista, continuar propagando a ideia de crítica como a realização do sentido da história é algo completamente extemporâneo. Ninguém mais tem o direito de falar em nome da história e nenhum sujeito ou agente social é o detentor da verdade entendida como algo unívoco. Um outro problema é que não temos mais aquele otimismo dos séculos XVIII e XIX a respeito da unicidade da humanidade. Poucos acreditam hoje num projeto de libertação que inclua todas as culturas e civilizações, todos os povos num único modelo societário para o futuro. Cada vez mais se valorizam as diferenças e as alteridades, a questão dos Outros, com suas diferentes concepções a respeito do ideal de uma sociedade no futuro.

Isso posto, cabe uma interrogação: qualquer discurso que critique outro(s) no sentido de incorporá-lo numa nova síntese, e que contenha um projeto qualquer de autonomia, pode ser considerado crítico? Exemplificando: se pensarmos numa perspectiva cristã fundamentalista, adepta do criacionismo, crítica seria uma compreensão dos fundamentos e limites da ciência - neste caso, do neodarwinismo - procurando superá-la com o ato de a incorporar como parte de uma teoria que mantivesse os dogmas da religião e ao mesmo tempo admitisse certas mudanças temporais na natureza e no advento dos seres vivos. (E também existiria um projeto de autonomia ou libertação nesse caso, mesmo que em outra vida). O mesmo poderíamos admitir para os fundamentalistas islâmicos, para os hinduístas, para os adeptos da supremacia branca, etc.

Cairíamos então num relativismo segundo o qual todos os pontos de vista se equivalem e, assim sendo, qualquer discurso que procurasse compreender uma teoria e incorporá-la num projeto qualquer de "libertação" seria considerado crítico? É evidente que não. Então, como sair desse empasse?

Em primeiro lugar, temos que lembrar que para Kant existe um vínculo indissociável entre crítica e democracia, sendo esta um processo que implica na crescente libertação da humanidade em relação às crendices, ao autoritarismo, às tradições que reproduziam ou reproduzem uma sociedade rigidamente estratificada e com privilégios para alguns. Crítica, nessa concepção kantiana e moderna, deve ser algo que contribui para a liberdade e a igualdade dos seres humanos, e nunca algo que justifique ou legitime qualquer tipo de ditadura, de autoritarismo ou de totalitarismo, de privilégios, de racismo ou de preconceitos. Não vivemos mais uma batalha entre direita e esquerda, tampouco entre capitalismo e socialismo. Um intelectual que enxergou muito bem um dos principais conflitos neste novo século foi o escritor Francis Wheen, que afirmou que: "A nova batalha será entre $o$ melhor do legado do Iluminismo (racionalismo, empirismo científico, separação da Igreja e do Estado) por um lado e, do outro, várias formas de obscurantismo e relativismo destituído de valores, freqüentemente mascarado como 'antiimperialismo' ou 'antiuniversalismo' - para dar um verniz atraente radical a atitudes profundamente reacionárias" (WHEEN, 2007). 
Assim sendo, não tem sentido adotar aquela posição comodista que considera críticas determinadas ideias que servem de propaganda para fundamentalismos ou dogmatismos, mesmo que elas sejam extremamente ácidas em relação ao capitalismo, que é exorcizado como o demônio do nosso tempo. Críticas essas, por sinal, que estão mais para o "falar mal" de algo e nunca para a análise de seus fundamentos e limites; que no fundo constituem tão somente impropérios a respeito do capitalismo, da globalização e até mesmo da democracia.

Em segundo lugar, temos que levar em conta que a geografia é ou pretende ser uma ciência. O que Kant almejava com a sua crítica como prolongamento do iluminismo era exatamente libertar a humanidade das amarras dos dogmatismos e dos autoritarismos, da escuridão enfim; e que essa iluminação através da razão era comandada pela ciência moderna. O escopo da ciência - ou melhor, das ciências, no plural, para evitarmos o mito de um método único para todos os aspectos do real - é desenvolver ou dilatar o conhecimento humano sobre a realidade em todas as suas dimensões. Um conhecimento que, não raro, serve para ampliar nosso controle sobre a natureza, tanto a interna (nosso corpo e mente) como a externa (através da redução das distâncias, da ampliação da oferta de alimentos, ou mesmo de novas substâncias, da produção de máquinas e até de armamentos, etc).

Sem dúvida que esse controle hoje, ao contrário dos séculos XVIII e XIX, é tido como problemático. Sabemos que muitas vezes ele gera consequências nocivas para determinados ecossistemas e grupos humanos ou, em alguns casos, até mesmo para a biosfera e para a humanidade como um todo. Contudo, bem ou mal, ele sempre foi e continua sendo o motor que impulsiona o chamado desenvolvimento, inclusive nas suas possíveis formas sustentáveis. Mesmo que critiquemos o conhecimento científico - algo que, como vimos, faz parte do seu próprio modo de ser, no qual a crítica é necessária para suas correções e rearranjos. Mesmo que deneguemos essa excrecência da ciência moderna, o cientificismo, que advoga uma absurda atitude arrogante e imperialista frente às demais formas de conhecimento - desde o artístico ao filosófico, passando pelos diversos sensos comuns, pela experiência de vida das comunidades tradicionais e dos povos ditos selvagens, etc.. Mesmo assim, os cânones do conhecimento científico continuam sendo a melhor maneira de superar o relativismo puro e simples e avançar nessa problemática do que é uma atitude crítica hoje.

Um dos grandes méritos da ciência ou das ciências é admitir que suas verdades, embora frequentemente úteis e eficazes, são sempre provisórias e sujeitas a correções ou superações. O conhecimento científico não procura nem aceita o Absoluto. Ele relativiza os conceitos e teorias, embora não no sentido do relativismo ingênuo, ou puro e simples, na qual tudo é igual e portanto não existe qualquer hierarquia e tampouco nenhuma forma de aprimoramento ou avanço gradativo do conhecimento. A ciência relativiza os conceitos e teorias - e até mesmo os objetos - ao considerá-los como verdades provisórias e sempre sujeitas a testes, a confrontos com a realidade e com outras explicações, mas cujo sentido, mesmo havendo encontros e desencontros, avanços e possíveis recuos, sem dúvida que tem um norte, que é um crescente acúmulo de informações cada vez mais eficazes no sentido de compreender (e agir sobre) o mundo, o real em todos os seus aspectos.

É justamente aqui que encontramos a via que nos permitirá reconhecer a criticidade numa teoria, num discurso: a sua relatividade em termos de contextualização e significado para o universo do qual faz parte. Não existem ideias ou teorias críticas em si. Elas só o são em função do papel que desempenham no seu contexto, razão pela qual podem ser críticas numa época, num momento e num lugar determinados - por exemplo, o marxismo na Europa Ocidental do século XIX - e também podem ser completamente acríticas em outra época ou lugar, tal como ocorre, como já mencionamos, com o marxismo em praticamente todo o mundo nos dias de hoje.

Voltando agora para a seara da geografia, podemos seguir com a inquietação de Blomley. 
Sem dúvida que existe uma certa verdade na afirmação que há diferentes vertentes autodenominadas críticas na geografia (como na ciência social e na filosofia em geral) e que talvez o melhor seja deixar de lado esse adjetivo, pois afinal de contas, já não teria ele cumprido o seu papel? (Que foi o de servir de bandeira de luta contra a geografia tradicional, que praticamente não existe mais ou pelo menos já não conta com teóricos que a defendam).

Mas, por outro lado, cabe uma indagação. Como os geógrafos ditos críticos vêm enfrentando esse problema da crítica? Uma parte deles, felizmente minoritária (talvez não na América Latina), continua a agir e escrever como se nada de importante tivesse ocorrido nos últimos anos e décadas, como se vivéssemos ainda uma luta entre "esquerda" (os adeptos do socialismo e críticos do capitalismo) e "direita" (os adeptos do capitalismo, que seriam por definição conservadores e inimigos do pensamento crítico). Crítica aqui é entendida como "falar mal" dos demônios do nosso tempo: o capitalismo, naturalmente, junto com a globalização vista como neoliberal, a democracia "burguesa" e a imprensa livre (principalmente quando esta desanca regimes autoritários e populistas "de esquerda", quando denuncia os abusos dos direitos humanos em Cuba, etc.). São produzidos panfletos - ou estudos pouco fundamentados, onde o objeto criticado sequer é compreendido de fato - nos quais via de regra existe uma interpretação paranoica ou conspiracionista da história: foi a CIA quem promoveu os atentados de 11 de setembro de 2001 com vistas a obter apoio para as invasões do Afeganistão e do Iraque, as cobranças de organizações internacionais, especialmente o Banco Mundial, com a qualidade do sistema escolar é apenas parte de um projeto neoliberal com vistas a privatizar o nosso ensino público, as preocupações com os desmatamentos na Amazônia são meramente uma faceta do imperialismo que objetiva internacionalizar aquela região (o que significaria deixá-la aos cuidados dos países ricos, principalmente dos Estados Unidos), as denúncias de presos políticos em Cuba ou da pobreza e do autoritarismo na Coreia do Norte ou na Venezuela no fundo fazem o jogo do imperialismo norte-americano, que almeja derrubar aqueles regimes revolucionários, etc. Para esta vertente o pluralismo é um mal, o marxismo [entendido como se fosse algo unívoco] é o único "método" científico válido, as citações de algum autor (seja do próprio Marx ou, mais frequentemente, de algum marxista posterior) substituem as análises ou até mesmo o raciocínio, não existiria nenhum aspecto positivo na globalização e nas novas tecnologias, mas tão somente uma constante ampliação das desigualdades sociais e espaciais, e por aí afora.

Contudo, sem dúvida que existem sérias tentativas de renovar dentro das geografias críticas, que não são meramente panfletárias e comodistas, que procuram enfrentar os desafios de uma nova realidade, inclusive aquele da crise do marxismo e da absoluta incapacidade de grande parte das geografias críticas e principalmente das radicais de incorporar essa questão até os primórdios dos anos 1990. Nem todos os geógrafos ditos críticos são dogmáticos e meramente reproduzem estereótipos. Existe uma vertente crítica na boa acepção do termo, que procura realizar uma análise crítica tanto do capitalismo como também - ou talvez mais ainda - do socialismo real, que buscou e busca subsídios não apenas no marxismo (embora também criticado pelo reducionismo econômico e principalmente pela valorização do tempo em detrimento do espaço), mas notadamente nos anarquismos (especialmente de Reclus e Kropotkin), em Foucault e na pós-modernidade. Mencionando apenas um exemplo entre muitos, uma expressiva parte dos geógrafos autointitulados críticos, ao constatar as radicais mudanças no capitalismo e o final do socialismo real, vem procurando nos últimos anos renovar as suas teorias com o uso de conceitos ou ideias da teoria crítica, isto é, da Escola de Frankfurt, em especial as de Habermas. Um dos expoentes dessa vertente, ao procurar superar a "geografia radical" e construir uma "geografia crítica", assim se expressou:

"As correntes radicais da geografia, em todas as suas variantes, não apenas procuraram elaborar uma crítica do positivismo lógico, como 
também efetuar mudanças sociais e políticas. Em face do visível êxito do capitalismo nos anos 1980 e da queda dos regimes comunistas da Europa durante os anos 90, a geografia radical fracassou retumbantemente nos seus objetivos práticos. No exame das razões desse fracasso, devemos reexaminar as cinco características chaves da teoria crítica de Habermas: as relações entre teoria e prática, a teoria dos interesses cognoscitivos, a teoria da competência comunicativa, o interesse pela emancipação e a prática da autoreflexão. (...) O trabalho da geografia crítica consiste em exprimir as desigualdades e convencer as pessoas do poder sobre suas prováveis repercussões, além de participar ativamente na criação de novas formas de organização social e econômicas. Em poucas palavras, devemos reconhecer o mal estar de nossa sociedade, adotar uma postura autoreflexiva frente a ela e atuar como psicanalistas da situação da qual fazemos parte." (UNWIN, 1991: 250-3).

Notamos um grande avanço nessa proposta que, como havia assinalado Blomley, significa a passagem de uma geografia radical para uma geografia crítica. Pois crítica não se identifica com - embora pressuponha- um mero engajamento. $O$ engajamento com os problemas sociais e territoriais, inclusive os ambientais, foi a grande bandeira de luta dos radicais anglosaxônicos contra a geografia que predominava na sua realidade até o final dos anos 1960: a geografia pragmática ou quantitativa, voltada para planejamentos e aparentemente "técnica" ou "neutra". Ele teve o seu papel positivo. Mas o mundo mudou, os problemas se modificaram alguns se ampliaram, outros se contraíram, outros novos surgiram e outros ainda adquiriram distintas facetas - e o simples engajamento, embora necessário, se tornou problemático. Engajamento, por sinal, que de forma visível hoje pode denotar uma atitude intransigente, antidemocrática ou até terrorista. Principalmente quando tido como "radical" 8 . Não existe engajamento apenas por um "outro mundo" ou um "mundo melhor" (e, afinal de contas, o que quer dizer "melhor"?, sem dúvida algo que pode ser defendido com convicção até mesmo por neonazistas, maoistas, bolivaristas e vários outros tipos político-ideológicos com viés autoritário). Assim, os termos radical e crítica não se identificam completamente. Eles podem se sobrepor em algumas ocasiões, mas em geral apontam para atitudes diferentes. Voltando à proposta de Unwin, observamos que nela o papel do geógrafo crítico não é o de meramente ser um terrorista intelectual ou um incendiário - isto é, um engajado de forma radical - e sim um "psicanalista" que detecta problemas e ao mesmo tempo potenciais. Como se sabe, o psicanalista não destrói a personalidade que analisa e sim a reconstrói, a ajuda no seu encontro, na superação dos seus problemas e fobias. [Alguns diriam, citando Gramsci, que para o novo nascer o velho tem que morrer. Talvez sim, mas somente num sentido metafórico. Pois o novo sempre significa um certo prolongamento, com determinadas nuanças, do velho. Não se trata do nascimento de um indivíduo que vai - depois de várias décadas - substituir um outro que envelhece e morre. Essa visão organicista é equivocada na medida em que é a mesma sociedade, embora transformada, que perdura. Ela pode mudar sua estrutura produtiva, revolucionar seus valores, melhorar substancialmente a qualidade de vida de seus membros. Mas sempre haverá uma certa continuidade, uma herança que permanece. O velho, portanto, nunca morre totalmente. É por isso que ainda hoje somos herdeiros dos egípcios, dos gregos e dos romanos da antiguidade ${ }^{9}$, dos iluministas do século XVIII ou dos socialistas [no plural] do século XIX. Ademais, a filiação desse geógrafo à teoria crítica na sua versão habermaniana pressupõe uma aversão ao tradicional dogmatismo do marxismo-leninismo e principalmente uma aceitação da democracia, que ao invés de ser combatida deve ser preservada e inclusive expandida. Mesmo sem concordarmos inteiramente com a posição de Unwin [deixando de lado, por ora, o porquê disso], não podemos deixar de elogiar o avanço teórico e político contido na sua proposta [como também na de Blomley e outros] de uma transição da geografia radical para uma geografia crítica pósmarxista aberta e plural. 


\section{Notas}

$1 \mathrm{Na}$ verdade, estamos generalizando de forma proposital para evitar discorrer sobre as controvérsias a respeito da utopia no pensamento crítico (que nunca foi nem é apenas marxista), na qual há autores que a a exorcizam e outros que a assumem. Por exemplo: Marx e Engels, em primeiro lugar, além de grande parte dos marxistas do início do século XX (Lénin, Trotsky, Rosa Luxemburgo, Kautsky...) nunca foram adeptos da utopia e, pelo contrário, desancaram os socialistas utópicos acreditando firmemente que o socialismo não era uma idéia utópica e sim "científica", um resultado de "leis" inexoráveis da História (assim mesmo, com H maiúsculo). A respeito da aversão do pensamento marxiano pela utopia remeto às análises de FAUSTO (2007: 31-50). Em todo o caso não há dúvida que, durante o transcorrer do século $\mathrm{XX}$, o projeto socialista passou a ser visto como utópico e essa defasagem entre ciência e utopia se estreitou sensivelmente.

2 Por exemplo, http://www.jiscmail.ac.uk/lists/critgeog-forum.html, fórum de geografia crítica existente desde março de 1996.

3 É bem verdade que com a expansão da geografia crítica para a Itália, Espanha, Brasil e outros países da América Latina, um certo marxismo-leninismo com fortes influências de Althusser e discípulos passou a ocupar o lugar do pensamento pósmoderno, pelo menos em grande parte, conforme já havíamos assinalado em dois textos dos anos 80 (VESENTINI, 1984 e 1985). Basta lembrar, por exemplo, do livro extremamente dogmático do geografo italiano Massimo QUAINI (1979), que conseguiu enxergar nos escritos de Marx e de Engels toda uma análise e até mesmo a "solução" para os problemas ambientais e territoriais hodiernos! Em todo o caso, mesmo continuando a existir uma forte presença de marxistas ortodoxos nesta geografia [aqueles que têm por base teórica e filosófica os escritos de Lénin, Althusser e discípulos como Martha Harnecker (com a sua leitura estruturalista e empobrecida da obra de Marx), o velho Lukács ou Trotsky], não há dúvidas de que ela avançou no sentido de incorporar autores marxistas heterodoxos ou neomarxistas (como Léfebvre), autores pós-marxistas (como
Habermas) e até mesmo pós-modernos (como Foucault, Guattari, Giddens e outros).

4 Até mesmo alguns poucos cientistas sociais incorporaram esse viés equivocado. Um autor brasileiro bastante citado e tido como especialista em metodologia científica, por exemplo, asseverou que: "Do ponto de vista metodológico, critica é sempre negativa. Crítica 'positiva' é outra coisa, quer dizer, é elogio." (DEMO: 2002:30).

5 " $A$ postura crítica torna-se, assim, um instrumento de pesquisa: a crítica é um instrumento de progresso [científico]; é a crítica que distingue a postura científica da experiência pré-científica, onde se fazem erros e se espera até que se esteja arruinado com eles(...) Quando se tem postura crítica, explora-se os erros de forma positivamente crítica, aprendendo-se conscientemente a partir deles." (POPPER, 1994:51).

6 Claude LEFORT (1979: 249) foi um dos primeiros a perceber isso, tendo sugerido que o proletariado foi mais uma invenção da "fértil imaginação de Marx".

7 Como já havia assinalado muito bem CASTORIADIS (1982: 82-5), o marxismo no século $X X$ pouco a pouco degenerou numa ideologia da burocracia, num discurso legitimador de um partido ou um grupo de burocratas que pretende alcançar o poder e/ou que já o exerce de forma totalitária, isto é, sempre reprimindo violentamente as críticas e oposições, que são taxadas de "burguesas" e antirrevolucionárias, e sempre falando em nome de uma pretensa comunidade dos trabalhadores, do povo ou do proletariado.

80 termo radical, ao contrário de crítica, não possui uma rica tradição filosófica e epistemológica. Na verdade ele veio do latim [radic $=$ raiz] e, deixando de lado o seu uso na matemática, na química, na linguística, etc., ele tem dois significados principais. Primeiro, denota uma atitude intransigente, inflexível, sem um verdadeiro diálogo com os outros. Segundo, e de acordo com a sua origem etimológica, significa ir às origens ou à raiz das coisas. É amplamente conhecida a frase tautológica de Marx segundo a qual "a raiz do Homem é o próprio Homem", ou melhor, as suas relações no 
mundo do trabalho. O problema é que os dois significados frequentemente se misturam inclusive em Marx, famoso pela sua arrogante intransigência frente a qualquer ideia que não as suas [inclusive dos socialistas utópicos, anarquistas, etc.] - e, ademais, a "raiz" das coisas, exceto das árvores, é algo extremamente problemático: para os geneticistas a raiz de um indivíduo está na sua herança genética, para determinados antropólogos e também num outro plano, para os psicanalistas, a raíz de uma sociedade está nos seus mitos e valores, para os ecologistas está nas relações com a natureza, e assim por diante.

9 FREUD (1997), por exemplo, analisou com argúcia como o egípcio Moisés propagou uma religião monoteísta cujos mitos até hoje influenciam uma grande parte do mundo. Quanto à importância da filosofia - e das artes - grega ou do direito romano para a nossa vida atual, creio que é desnecessário insistir nesse item.

\section{Referências Bibliográficas}

BERMAN, Marshall. Tudo que é sólido desmancha no ar. A aventura da modernidade. São Paulo, Companhia das Letras, 1987.

BLOMLEY, Nicholas. Uncritical critical Geography? In : Progress in Human Geography. Vol.30, n.1, 2006, pp.87-94.

BOBBIO, N. Esquerda e Direita. São Paulo, Editora Unesp, 1995.

CARROLL, Robert. The Skeptic's Dictionary, disponível in http://www.skepdic.com/, consultado em julho de 2007.

CASTORIADIS, C. - A instituição imaginária da sociedade. Rio de Janeiro, Paz e Terra, 1982.

DEMO, Pedro. Mitologias da avaliação. São Paulo, Cortez, 2002.

FAUSTO, Ruy. A esquerda difícil. São Paulo, Perspectiva, 2007.

FOUCAULT, M. Qu'est-ce que la critique? Critique et Aufklärung. In : Bulletin de la Société Française de Philosophie, Vol. 82, no 2, avr/juin 1990, pp. 35-63.

FREUD, S. Moisés e o monoteísmo. São Paulo, Imago, 1997.

GIDDENS, A. Para além da Esquerda e da Direita. São Paulo, Unesp, 1995.
HARVEY, D. Spaces of Capital. Towards a Critical Geography. New York, Routledge, 2001.

LACOSTE, Y. A Geografia - isso serve, em primeiro lugar, para fazer a guerra. Campinas, Papirus, 1988.

LEGRAND, Gerard. Dicionário de Filosofia. Lisboa, Edições 70, 1986.

LEFORT, Claude. As formas da História. São Paulo, Brasiliense, 1979.

A invenção democrática. São Paulo, Brasiliense, 1983.

NOVE, Alec. A economia do socialismo possível. São Paulo, Ática, 1989.

POPPER, Karl. O racionalismo crítico na política. Brasília, Editora da UNB, 1994.

QUAINI, M. Marxismo e Geografia. Rio de Janeiro, Paz e Terra, 1979.

SEN, Amartya. Desigualdade reexaminada. Rio de Janeiro, Record, 2001.

SIERRA, Pelayo Garcia. Diccionario Filosófico. Biblioteca Filosofía en Español, Oviedo, 1999.

SMITH, Neil. What is left? Neo-critical Geography, or the flat pluralist world of business class. In: Antipode. A Radical Journal of Geography. Vol.37, Issue 5, november 2005, pp.887-889. 
THRIFT, Nigel e AMIN, Ash. What is Left ? Just the Future. In : Antipode. A Radical Journal of Geography. Vol.37, Issue 5, November 2005, pp.220-238.

UNWIN, Tim. The place of Geography. London, Longman Group, 1992.

VESENTINI, J.W. Percalços da geografia crítica: entre a crise do marxismo e o mito do conhecimento científico. In: Anais do $4^{\circ}$. Congresso Brasileiro de Geógrafos. São Paulo, AGB, 1984, Livro 2, Vol.2, pp.423-32.

- Geografia e discurso crítico (da epistemologia à crítica do conhecimento). In:
Revista do Departamento de Geografia 4. São Paulo, USP, 1985, pp.7-13.

WHEEN, F. Answer to the question: Left and right defined the 20th century. What's next?, in Prospect, march 2007, http:// $w w w$. prospect-magazine.co.uk/ article_details.php?id $=8342$, capturado em março de 2007.

WILLS, Jane. What's left? The left, its crisis and rehabilitation. In: Antipode. A Radical Journal of Geography. Vol.38, Issue 5, November 2006, pp.907-15.

Trabalho enviado em fevereiro de 2009 Trabalho aceito em setembro de 2009 
